\title{
2013 Curriculum Reflected in an International Oriented Senior High School, Yogyakarta
}

\author{
Noor Chairani \\ Ahmad Dahlan University, Yogyakarta, Indonesia
}

\begin{abstract}
Curriculum is one of important factors which contribute to improving learner's ability and potency in education. Curriculum used in school has a purpose to make learners be active and creative persons. It is an education plan that emphasizes the competency of learners. Indonesia, through its Ministry of Education, implements 2013 Curriculum officially that reflects the competency of learners. This curriculum is actually similar with competence-based curriculum which concentrates on learners. In senior high school level, English becomes one of the subjects of final national examination and also this is the last level for learners before they continue their study to university. International oriented school is a school that applies English as a second language and also a school cooperates with or uses international standard curriculum. Reflecting learning and teaching English in senior high school especially in the international oriented school is very important and needs special attention. This research investigates the implementation of curriculum in the international oriented senior high school in Yogyakarta. From the research, it is known that the school officially does not implement 2013 Curriculum. However, ACT (Assessment Certificate Test) curriculum and the values of the school automatically reflect the 2013 Curriculum because the school empowering implementation of competency-based curriculum in learning process that focuses on learner-centered learning, facilitating assessments of process of learning and fostering learners' autonomy through the curriculum is reflected in the school essentially in the programs and activities.
\end{abstract}

Keywords: senior high school, international oriented school, 2013 Curriculum

\section{Introduction}

Among various sources of education, curriculum is the most significant element which contributes to improving learners' ability and potency (Richard, 2001, p. XI). Accordingly, curriculum that emphasizes competency is very crucial and needed. Such curriculum should become an instrument which guides learners to become: (1) qualified human beings who are able to face the challenge of time proactively; (2) educated human beings who are faithful, have piety toward the Lord, and have good morals, knowledgeable, creative, and self-directed; and (3) democratic and responsible citizens. The implementation of competency-based curriculum is one of the strategies of national education building as stated by the Undang-undang Sisdiknas no 20 tahun 2003 (Law 20 year 2003 on National Education System) (Ministry of Education and Culture, 2012, p. 3).

Conceptually, curriculum responds to education system toward the need of society and nation in building young generation. Pedagogically, curriculum is an education plan which gives learners the opportunity to develop their potency in a pleased condition of learning and appropriate with his ability to be a qualified man

Noor Chairani, S.Pd., M.Hum., post graduate, English Education Department, Ahmad Dahlan University. 
corresponding with the need of society. Curriculum is evolved according to standard and theory of education based on competency. Competency itself is an ability to behave and utilize knowledge and skill to carry out the duties and roles in the school, society, and environment in which the learners interact.

\section{Senior High School}

It is important, when discussing senior high school, to know the characteristic of learners in this level. Learners of senior high school are considered as adolescent, which is the level after young children and before adult. Adolescent term refers to learner from the ages of about 12 to 17 (Harmer, 2007). In this level, learners have great ability for abstract thought and they have passionate commitment to what they are doing once they are engaged. Senior high school learners are also bound up with a pronounced search for identity and a need for self-esteem. In this level, they need to feel good about themselves and valued. Thus, there is almost nothing more exciting than a class of involved young people at this age pursuing a learning goal with enthusiasm.

Herbert Puchta and Michael Schratz (Harmer, 2007) have stated that the teacher's failure in teaching for teenagers (senior high school learners) is caused by their inability to bridge what they want and have to teach their learners' world of thought and experience. Consequently, the material of learning has to be designed at adolescents' level, with topic which they can react to. They must be encouraged to respond to texts and situations with their own thoughts and experiences, rather than just by answering questions and doing abstract learning activities. The teacher must give them tasks which they are able to do, rather than risk humiliating them.

Developing learners' participation in teaching learning process is important. Such participation will help them to be autonomous learners and improve their intrinsic motivation. Making learners become autonomous learners is essential because when they get learning autonomy, they will learn more than currently. They learn also without teacher's presence, which means that they also learn outside the class. Their participation will also improve their intrinsic motivation since they will choose the activities or materials which they are interested in. Besides, learners will be more creative, too, because they will try hard to find things which are interesting to them and think more about what they want to do and say. The target of English learning and teaching in senior high school is to enable the learners to use English language to communicate. In other words, the target is to make learners to be able to use English language functionally for their daily conversation both in oral and written form.

\section{International Oriented School}

In essence, schools describe themselves as international schools for a variety of reasons including the nature of the learner population and of the curriculum offered, marketing and competition with other schools in the area, and the school's overall ethos or mission (Hayden, 2006, p. 10). In terms of phase, size, and sex, international schools defy the definition: They may include kindergarten, primary, middle, and upper, higher or secondary pupils, or incorporate all of these in a combined school; they may range in number from twenty to 4,500; they could be co-educational or single sex. The governance and management of such schools might be determined by the school, the owner, the board, the senior management team, or the head of school or the managing agency (Hayden, 2006, p. 12).

However, official resource defines international school as a school that promotes international education, 
in an international environment, either by adopting an international curriculum or by following a national curriculum different from that of the country the school is located in. More specifically, at a conference in Italy in 2009, the International Association of School Librarianship came up with a list of criteria for describing an international school (Skirrow, 2009). They are as follows: (1) transferability of the student's education across international schools; (2) a moving population (higher than in state schools or public schools); (3) multinational and multilingual student body; (4) an international curriculum (e.g., IB-DP, MYP, PYP); (5) International accreditation (e.g., CIS, IBO, North Eastern ASC, Weston ASC. of Schools and colleges were mentioned by the group); (6) a transient and multinational teacher population; (7) non-selective student enrollment; and (8) English or bilingual used as an instructional language.

An international school facilitates learners to become global citizens by providing rigorous and comprehensive education with full immersion into multiple languages and cultures. Learners attend these schools to learn the language of the international school and to obtain qualifications for employment or higher education in a foreign country. Hayden and Thompson (quoted by James Cambridge, 2001) mentioned five core "universals of international education". We can articulate that those cores exist in international school: (1) diversity in student cultures; (2) teachers as exemplars of "international mindedness"; (3) exposure to others of different cultures outside the school; (4) a balanced formal curriculum; and (5) a management regime value-consistent with institutional international philosophy.

According to Thompson (1998, pp. 278-280; also in Bates, 2011, pp. 132-133), there are four categorizations to devise curricula for use in international school, namely: (1) Exportation: the marketing abroad of existing national curricula and examinations, with little if any adjustment to take account of the different context and a value system "unapologetically that of the country from which it is exported"; (2) Adaptation: where existing national curricula and examinations are adapted for the national context, with the "inherent value system" not likely to change at all and the risk of, as Thompson puts it, an "unwitting process of educational imperialism"; (3) Integration: where "best practices" from a range of "successful" curricula are brought together into one curriculum for operation across a number of systems or countries (with attendant challenges potentially to be faced from the different values and ideological positions in question); and (4) Creation: the development of a program "from first principles".

In the international school context, one of languages in which the student will be aspiring for fluency (If they are not already a native speaker) is English. Sears (in Hayden, 2006, p. 64) proposes that there are now three agreed aspects to the effective support of second language English speakers in international schools: (1) mother tongue maintenance and development (in which the school's role varies); (2) an effective and integrated program of specific English language teaching in whatever form; and (3) the training of mainstream teachers in second language learning and culture issues and in the strategies necessary to give ESL (English as a Second Language) students access to the mainstream curriculum.

\section{Curriculum}

Curriculum can be defined as a group of plan and arrangement of goal, content, subject matter, and the way used as guidance of learning implementation to attain certain goals of education (Law number 20, 2003; Government Regulation number 19, 2005). Competency-based curriculum can be defined as curriculum designed in form of document, process and assessment based on goal attainment, content, subjects, and learning 
implementation in line with standard of graduate competency (Standar Kompetensi Lulusan: SKL).

Competency-based curriculum can be also identified as "outcomes-based curriculum". From the definition, improvement of curriculum should be directed toward attainment of competency formulated by standard of graduate competency (SKL). The outcome of learning and outcome of curriculum should also be measured by attainment of competency. According to Lili (2013, p. 21), we can summarize the focus of learning in 2013 Curriculum in four indicators, they are: (1) empowering implementation of competency-based curriculum in learning process; (2) empowering knowledge, skill, and attitude holistically in learning process; (3) empowering learner centered learning, from "learner told" to "learner look for the information from various resources"; and (4) empowering assessment of process and result.

The improvement of 2013 Curriculum from "curriculum for each education unit" (Kurikulum Tingkat Satuan Pendidikan, abbreviated by KTSP), to "competency-based curriculum" according to Ministry of Education and Culture is reflecting some principles. Those principles of improvement curriculum are: (1) Curriculum must be designed by giving opportunity to learners to improve the differences in skill and interest; (2) Curriculum must be centered on potency, improvement, need, and benefit of learners and his environment. Curriculum must be designed based on the principle that learners is on central position and must be active while learning; (3) Curriculum must be perceptive to change of knowledge, culture, technology, and art; (4) Curriculum must be relevant with need of life.

Through 2013 Curriculum which is competency-based curriculum, there are three domains that are hoped to be transformed, namely, (1) Graduate competency. Through 2013 Curriculum, graduates are expected to have good character, significant skill, and related knowledge; (2) Subjects. Through 2013 Curriculum, subjects are wished to be relevant with needed competency, become more essential and suitable for children development; and (3) Learning process. 2013 Curriculum will implement learner-centered active learning, contextual learning and text books contain material and process, system of assessment, and targeted competency.

Those transformations are described by the Table 1 below:

Table 1

Transformation of Curriculum in Indonesia

\begin{tabular}{ll}
\hline Previous curriculum & 2013 Curriculum \\
\hline Graduate competency & \\
\hline $\begin{array}{l}\text { Having not good character } \\
\text { Having irrelevant skill with the need } \\
\text { Having general knowledge }\end{array}$ & $\begin{array}{l}\text { Having good character } \\
\text { Having relevant skill } \\
\text { Having related knowledge }\end{array}$ \\
\hline Subject matters & \\
\hline Irrelevant with competency needed & Relevant with competency needed \\
Heavier (too many subject matter) & More Essential \\
Too wide, not deep & Suitable for children development \\
\hline Learning process & \\
\hline Teacher centered learning & Learner centered activate learning \\
Book oriented learning & Contextual learning \\
Text books contain only material for learning & Text books contain material and process of learning, system of \\
\hline Notes. Modified from Pengembangan Kurikulum (Ministry of Education and Culture, 2012).
\end{tabular}

Notes. Modified from Pengembangan Kurikulum (Ministry of Education and Culture, 2012). 
For the level of senior high school, there are some revisions in 2013 Curriculum. The revisions are: (1) There is a division between a group of obligatory subjects and a group of non-obligatory subject; (2) Non-obligatory subject is selected by learners according to their interest; and (3) There is no division of department like previous one, such as natural sciences class (IPA) and social sciences class (IPS). Briefly, the differences between "curriculum for each education unit (KTSP 2006)" and "2013 Curriculum" can be identified through the next Table 2:

Table 2

Essential Differences of Curriculum for Senior High School

\begin{tabular}{|c|c|}
\hline KTSP 2006 & 2013 Curriculum \\
\hline $\begin{array}{l}\text { Certain subject matters are supporting certain } \\
\text { competencies. }\end{array}$ & $\begin{array}{l}\text { All of subject matters are supporting all of competencies (attitude, skill and } \\
\text { knowledge) with different emphasis. }\end{array}$ \\
\hline $\begin{array}{l}\text { Subject matters are designed independently and } \\
\text { having their own basic competency. }\end{array}$ & $\begin{array}{l}\text { Subject matters are designed integrally and having basic competency with } \\
\text { core competency for each level. }\end{array}$ \\
\hline $\begin{array}{l}\text { Every subject matters are delivered with different } \\
\text { approaches. }\end{array}$ & $\begin{array}{l}\text { All of subject matters are delivered to learners with same approaches; } \\
\text { scientific approach through observing, questioning, trying, and reasoning. }\end{array}$ \\
\hline There is departmentization since senior high school. & $\begin{array}{l}\text { No departmentization in senior high school. There is a obligatory, inter } \\
\text { interest and deepening interest subject matters. }\end{array}$ \\
\hline Different competency between SMA and SMK. & $\begin{array}{l}\text { SMA and SMK are having same obligatory subject matters related to } \\
\text { knowledge, skill, and attitude. }\end{array}$ \\
\hline
\end{tabular}

Notes. Quoted from Lili Nulaili, Kurikulum 2013 dan Implementasinya di SMA (2013, p. 7).

\section{An International Oriented School Reflecting 2013 Curriculum}

Yogyakarta, one of famous cities in Indonesia and well known as an city of education, has many educational institutions, ranging from kindergarten to university. I have conducted an observation to one of international standard school in Yogyakarta. I observed three classrooms, which are class X, XI, and XII and carried out several interviews with some representative participants in the research. They were a deputy principal, two English teachers, a content-course teacher, a tutor, and twelve learners at an international oriented school. Totally, there were 17 participants interviewed in this research. All of the participants were from the school. The participants were selected to get valid information about the learning and teaching process reflecting the curriculums. This research used several kinds of instruments to gather the data, namely: note taking from observation of classes and also interview transcripts. These instruments were used to gain information in learning and teaching process in the school. The data sources were taken from participants to get more detailed data information based on their experience, their needs, and what they were reflected.

Based on the data gathered, it is known that the curriculum of the school is arranged based on some values, namely positive disciplinary, assertiveness, religious approach, art, and sportivity. The curriculum of the school emphasizes appreciation of the learner as a unique person. The school has three basic orientations, namely: (1) Equilibrium of logic and social intelligence: the development of capability to think systematically and actualize it in daily life; (2) Universalism of Islam: the comprehension of Islamic views; and (3) Global Citizenship: the encouragement of global competition as a world participant. Learners are encouraged to have awareness as a part of international community in participating as a world citizen. Then, it emphasizes the participants of the school using English as a communication medium in every activity of courses taken. The contents of curriculum consist of the core subjects (Math, Indonesian, and English), the orientation subjects (Universalism of Islam and Civic and Globalization), the supporting subjects (History and Chinese), the introduction of major 
subjects (Science, Social Study, Design and Art), the major selection subjects (Science major or Design and Art), and the selection subjects (Sport, Art, Languages, and Study club).

The school also adapts ACT (Assessment Certificate Test) as International standardized curriculum in which English is used as an instruction medium in learning and teaching process. The school hopes that it can make learners accustomed and more understand it in every situational context. Therefore, they have to use English in conversation as a medium of communication in the school. Only some subjects the learners should speak in Bahasa Indonesia such as Javanese, Chinese, SIL (Subject of Independent Learning), and History. The school, based on its profile, has a vision to create learners to have a critical thinking, social intelligent, Islamic universal values, and have conscious as one of world participants.

The international oriented senior high school Yogya also implemented "International" concept. It has two curriculums and two categories of classes. One curriculum adapts KTSP and the other one is ACT (Assessment Certificate Test) curriculum from America. Because it cooperates with International curriculum, the school divides the class into two classes, regular class and GAC (Global Assessment Certificate) one. Because GAC class adapts international curriculum (ACT one), the school declares two kinds of examination, national examination and GAC examination. In GAC class, every teacher uses English for instructional communication in many subjects. The purpose is to prepare the learners to face university level. Therefore, the school holds some programs to make them realize their orientation and also the major that they will be chosen by learners. Some real programs and activities every semester hold to encourage the learners to know the concept of many majors in the university level. They have field trip and home stay programs inside or outside of country every semester. The school digs learners' capability in many aspects and develops their talent. It also emphasizes the process by implementing assessments to control learners' progress.

\section{Conclusion}

2013 Curriculum incredibly emphasizes the activeness of learners in learning and teaching process. It is designed to give learning experiment broadly to learners to improve their attitude, skills, and knowledge. It is also the most significant element which contributes to improving learners' ability and potency as global citizen.

The international oriented senior high school investigated in this research inserts insight about the concept of university to learners in its learning and teaching process. Therefore, the learners can understand their interest and choose earlier the major of an undergraduate program. They will know their orientation through activities facilitated in the school. It can motivate them to be active in achieving target of education.

Although officially the school implemented KTSP collaborated with ACT curriculum, 2013 Curriculum essentially has been implemented in learning and teaching in the school as well through available subjects and activities in the school. So I can conclude that actually the school runs in the light of 2013 Curriculum because the school empowering implementation of competency-based curriculum in learning process that focuses on learner-centered learning, facilitating assessments in the process of learning and fostering learners' autonomy through the curriculum is reflected in the school essentially in the programs and activities.

\section{References}

Bates, R. (2011). Schooling internationally, globalization, internationalisation and the future for international school. New York: Routledge.

Harmer, J. (2007). The practice of English language teaching. Edinburgh: Pearson Educated Limited. 
Hayden, M. (2006). Introduction to international education, international schools and their communities. London: Sage Publication.

James, C., \& Thompson, J. (2001). Internationalism, international-mindedness, multiculturalism and globalization as concepts in defining international schools. Retrieved from http://staff.bath.ac.uk/edsjcc/intmindedness.html

Lili, N. (2013). Kurikulum 2013 dan Implementasinya di SMA (2013 curriculum and the implementation in senior high school). Retrieved from http://titoadidewantoblog.files.wordpress.com/2013/06kur-2013-dan implementasinya.pdf

Ministry of Education and Culture. (2013). Kurikulum 2013: Kompetensi Dasar Sekolah Menengah Atas (SMA)/Madrasah Aliyah (MA) (2013 curriculum: The basic competency of senior high school). Republik Indonesia: Kementrian Pendidikan dan Kebudayaan.

Richard, J. C. (2001). Curriculum development in language teaching. Cambridge: Cambridge University Press.

Skirrow, I. (2009). How to define an "International School"? Retrieved from http://iaslonline.ning.com/group/regioninternationalschools/forum/topics/how-to-define-an-international

Thompson, J. (1998). Toward a model for international education. In J. Thompson and M. Hayden (Eds.), International education principles and practice. Oxon: Routledge. 